\title{
Evaluation of Nutritional and Health Status of Prepartory School Student in Quisna- Menoufia Nutritional and Food Dept. of Sciences
}

\author{
Fatma El Zahraa Amein El Shrief, ${ }^{1}$ Azza Els-Eskafy, ${ }^{2}$ Aya Mohamed hassen El Far ${ }^{3}$
}

\begin{abstract}
It is of the at most importance to know much about the nutritional and health status of Egyptian adolescents, since in future they will be working people in all areas. In particular rural adolescents as in Menoufia governorate should have much attention, as the rural was neglected many years ago.
\end{abstract}

A total numbers of 60 females and 60 males, 11-14 years of age were chosen randomly from the preparatory schools of Qusina city- Menoufia governorarate. Anthropometric measurements were performed. Questionnaire included Socio-economic parameters, Food habits and daily intake of different nutrients was filled via interview. Statistical analysis was carried out by SPSS Statistical Program.

It was found that nutritional awareness was low for both genders in many items especially for boys calling for targeted nutritional awareness program. Daily intakes were low for Energy, Fat, Fibers, Vits. (A, D, C, niacin, Folat ), minerals (K, Ca, P, Fe, Zn). Health status was not satisfying for both girls and boys as well.

Key words: nutritional status, health status, food habits, anthropometric measurements, nutrition daily intakes.

\section{INTRODUCTION}

Adolescence, the transition from childhood to adulthood is accompanied by series physical, biochemical, hormonal and psychological changes. There is marked variation between sex and individuals in timing, intensity of changes during this period beginning with the appearance of sexual maturity and rapid growth. Girls tend to grow more rapidly between 12-14 years and boys experience this period growth between 14 and 16 years, there are many individual variation to growth pattern (Bendary, 1997).

Kirby and Danner, (2009) reported that pediatric nutritional deficiencies are associated not only with poverty in developing countries, but also in children in developed world who adhere to restricted diet, or taking too much food. In addition some practices were identified which are prevalent in several age groups including adolescents, and have important public health consequence, such as smoking, increased food intake (as fast foods) foods rich in fat, salt and sugar and low in zinc and calcium, besides iron, practicing no handwashing before food preparation and eating and neglecting weight-monitoring (Usfar and Fahmida, 2011).

Peykari et al., (2011) stated that most of female and male participants said that different factors influenced the girls and boys diet selection. Girls' paid more attention to diet selection and taste and health of foods, whereas boys were careless and gluttony caused more food consumed. They concluded that adolescents' information (both genders) regarding nutritional problems resulting from improper food habits were not satisfactory.

Al Sabbah et al., (2004) stated that there are many problems with adolescent eating, dieting and physical activity. Regional, gender and parental socioeconomic status differences should be taken into account in developing interventions. More detailed studies were needed with more elaborate instructions about food habits and physical activity of adolescents.

\section{MATERIALS AND METHODS}

\section{Sample:}

The total sample of this study composed of 120 students, which were chosen accedently from the preparatory school of Qusina city - Menoufia governorarate. A total numbers of 60 females and 60 males, 11-14 years of age were enrolled in the study.

\section{Period of study:}

The present study was carried out in 2013 .

\section{Data collection:}

The instrument used to collect data of present study consisted of a structured interviewing questionnaire, consisted of several parts. The first part was to obtain the anthropometric measurements, Which included the height $(\mathrm{cm}$ ), weight $(\mathrm{kg}$ ), body mass index (weight in $\mathrm{kg}$ / height in $\mathrm{m}^{2}$ ), triceps skinfold thickness (TSF in $\mathrm{mm}$ ), mid upper arm circumference (MAC in $\mathrm{cm}$ ), mid upper arm muscle circumference (AMC in $\mathrm{cm}$ using the formula $\mathrm{AMC}=\mathrm{AC}-3.14(\mathrm{TSF} / 10)(\mathrm{DRI}, 2002)$.

\footnotetext{
${ }^{1}$ Prof. of Nutrition \& Food Science, Ex - Dean Faculty of

Home Economics, Minufiya University

${ }^{2}$ Lecturer of Nutrition \& Food Science,.Faculty of

Home Economics, Minufiya University

${ }^{3}$ Faculty of Home Economics Menoufia University

Received August 20, 2013, Accepted September 24, 2013
} 


\section{The second part included socio-economic parameters:}

Socio-economic status act of questionnaire include the educational level of father and mother, family size, family monthly income and the The third part included studying expenditure on food habits:

Food habits included information collection about number of consumed meals, omitted meals, snacks, opinions of students about variable items of different food groups, as well as 24-hour recal.

\section{Analysis of nutrients of 24-hour food intake:}

The daily food intake had been assessed from the data collected using the 24-hour recall method. This included consumed foods in breakfast, lunch, dinner and snacks between meals or after dinner. Then data were analysed using Diet Analysis Program, (1995); the Consumer Program for Ready to Eat Egyptians Foods, Version 1, Food Analysis and Statistical Analysis Unit, Faculty of Home Economics, Menoufia University. Nutrients intakes were evaluated using DRI, (2002). According to DRI, energy requirements of boys and girls calculated as follows:

Girls: $135.3-(30.8$ age $)+\mathrm{PA}(10 \mathrm{wt}+934 \mathrm{ht})+25$

Boys: $88.5-(61.9$ age $)+\mathrm{PA}(26.7 \mathrm{wt}+903 \mathrm{ht})+25$

PA: factor for physical activity, being 1.31 and 1.26 for very and moderate activity girls and boys respectively.

\section{Statistical analysis:}

Statistical analysis was carried out in the Statistical Analysis Unit, Faculty of Home Economics, Menoufyia University by SPSS Statistical Program (SPSS, 1995).

\section{RESULTS AND DISCUSSION}

\section{A- Age and anthropometric measurements:}

Data presented in table (1) indicated no significant differences revealed between girls and boys in concern to height, age, TSF and AMC, although numerically girls showed higher values for height, age, TSF and less AMC. According to RDA (1989), the weight of boys and girls at mentioned age is 45 and $46 \mathrm{~kg}$, respectively. This indicated that the weight of all studied sample was much greater than RDA. According to Filer (1993), obesity is a significant risk when it appears early in life, and it is estimated that $70 \%$ of obese adolescents will become obese adults.

\section{B-Socio-economic characteristics:}

Results of table (2) indicated that father's education levels of boys group was higher than girls group, this because (illiterate + read and write $20.00 \%$ ) was lower than for girls $(33.30 \%)$.

Data presented in table (2) showed that mother's education levels of boys group were better than girls group, this because (illiterate + read and write) $31.66 \%$ was lower than girls $43.33 \%$, and for group (higher education of girls) $5.00 \%$ compared with boys group $(1.67 \%)$.

Results of table (2) showed that the family size (6-10 members) for girls $(73.34 \%)$ was higher than the boys $(65.00 \%)$. Moreover family size of 10 members recorded only for boys.

Data of table (2) revealed that family income level (400-900L.E and >900L.E) was $91.67 \%$ for girls but for boys was $88.33 \%$.

Data presented in table (2) indicated that for food expenditure, (60-66.67\%) of total sample belong to food expenditure $(50-75 \%)$ group rich indicates the higher price of food in Menoufia Governerate.(Unicef, 2010).

\section{C- Food habits:}

Results of table (3) indicate the fact that about 26.67 of boys and 16.67 of girls healthy omit breakfast, being undesirable food habit, which may affect the health of adolescents and productivity. As for kind of snacks taking between meals, it is obvious that soft drinks, called the follow food were more consumed by girls (8.32) than boys $(6.67 \%)$. As for sugar spoon number, it could be observed that the lowest number of girls consumption of sugar (three spoon) was by $27(45 \%)$ comparing to boys $30(50 \%)$. Moreover both percentage of girls and boys who certainly take milk were low being $31.67 \%$ and 16.67 , respectively, calling for nutritional programs to enhance taking milk in particular for the boys group.(Croll et al., 2001).

\section{D- Nutrition awareness:}

Data presented in table (4) illustrate the opinions of adolescents (girls and boys) about the bread, seeds and cereal groups. It is clear that $98.33 \%$ of girls believe that balady bread is better than fino bread. Boys who stated wrong answers amounted to $8.33 \%$ in contrast to only $1.67 \%$ of girls. More boys (91.67\%) than girls (86.67\%) believed that horse bean is a main source of proteins in Egypt. More girls (81.67\%) than boys (78.33\%) indicated that bread is a rich source of carbohydrates.

Data presented in table (4) indicated that most of boys and girls 58\%:72\% respectively believed that fruits and vegetables proteins are not equivalent to that of meat protein, meanwhile mistaken girls $(28.33 \%)$ were more than those of boys (25\%). More boys $(85 \%)$ than girls $(73.33 \%)$ believed right that fish is more useful than meat concerning the nutritional value. More girls $(75 \%)$ than boys $66.67 \%$ indicated that liver is a rich source of iron. Unfortunately, 25\%:33\% of total sample did not know this fact. Data of table (4) showed that girls $(81.67 \%)$ and boys $(58.33 \%)$ believed right that milk is not rich in irons in this connection more boys $(41.47 \%)$ than girls.(18.33\%) were mistaken. 
Table 1. Mean and standard devian on of age and Anthropometric measurements among the sample

\begin{tabular}{lccc}
\hline \multirow{2}{*}{ Variable } & Girls N=60 & Boys N=60 & \multirow{2}{*}{ sig } \\
\cline { 2 - 3 } & Mean \pm SD & Mean \pm SD & \\
\hline Age & $13.45 \pm 1.11$ & $13.07 \pm 0.99$ & $*$ \\
\hline Height $(\mathrm{CM})$ & $156.92 \pm 8.32$ & $154.63 \pm 6.27$ & \\
\hline Weight $(\mathrm{KG})$ & $52.89 \pm 8.31$ & $49.45 \pm 8.86$ & \\
\hline $\mathrm{TSF}(\mathrm{cm})$ & $3.02 \pm 0.44$ & $2.75 \pm 0.45$ & $*$ \\
\hline $\mathrm{AMC}(\mathrm{cm})$ & $12.41 \pm 1.81$ & $13.07 \pm 0.99$ & $*$ \\
\hline $\mathrm{BMI}\left(\mathrm{kg} / \mathrm{m}^{2}\right)$ & $21.38 \pm 2.78$ & $20.53 \pm 3.15$ & \\
\hline $\mathrm{AC}(\mathrm{cm})$ & $21.94 \pm 2.02$ & $22.35 \pm 2.53$ & \\
\hline
\end{tabular}

Table 2. Socio-economic characteristics

\begin{tabular}{|c|c|c|c|c|}
\hline \multirow{2}{*}{ Groups } & \multicolumn{2}{|c|}{ Girls } & \multicolumn{2}{|c|}{ Boys } \\
\hline & Frequency & $\%$ of total & Frequency & \% of total \\
\hline \multicolumn{5}{|c|}{ Father Education Level: } \\
\hline Illiterate & 4 & 6.7 & 2 & 3.33 \\
\hline Read and Write & 16 & 26.6 & 10 & 16.67 \\
\hline Secondary & 4 & 6.7 & 15 & 25 \\
\hline Intermediate & 21 & 35.0 & 22 & 36.67 \\
\hline Education & 13 & 21.7 & 10 & 16.67 \\
\hline Higher Education & 2 & 3.3 & 1 & 1.67 \\
\hline Total & 60 & 100 & 60 & 100 \\
\hline \multicolumn{5}{|c|}{ Mother Education Level: } \\
\hline Illiterate & 6 & 10 & 5 & 8.33 \\
\hline Read And Write & 20 & 33.33 & 14 & 23.33 \\
\hline Secondary & 5 & 8.33 & 9 & 15 \\
\hline Intermediate & 17 & 28.34 & 19 & 31.67 \\
\hline Education & 9 & 15 & 12 & 20 \\
\hline Higher Education & 3 & 5 & 1 & 1.67 \\
\hline Total & 60 & 100 & 60 & 100 \\
\hline \multicolumn{5}{|c|}{ Family Size (Member): } \\
\hline 4 members & 1 & 1.67 & 1 & 1.67 \\
\hline 5 members & 15 & 25 & 20 & 33.33 \\
\hline 6 members & 25 & 41.67 & 23 & 38.33 \\
\hline 7 members & 13 & 21.67 & 10 & 16.67 \\
\hline 8 members & 5 & 8.33 & 3 & 5 \\
\hline 9 members & 1 & 1.67 & 2 & 3.33 \\
\hline 10 members & 0 & 0 & 1 & 1.67 \\
\hline Total & 60 & 100 & 60 & 100 \\
\hline \multicolumn{5}{|c|}{ Family Income (L.E): } \\
\hline$<400$ & 5 & 8.33 & 7 & 11.67 \\
\hline $400-900$ & 36 & 60 & 38 & 63.33 \\
\hline$>900$ & 19 & 31.67 & 15 & 25 \\
\hline Total & 60 & 100 & 60 & 100 \\
\hline \multicolumn{5}{|c|}{ (2-e):Food Expenditure on food } \\
\hline $25 \%$ & 11 & 18.33 & 14 & 23.33 \\
\hline $50 \%$ & 25 & 41.67 & 13 & 21.67 \\
\hline $75 \%$ & 15 & 25 & 23 & 38.33 \\
\hline No answer & 9 & 15 & 10 & 16.67 \\
\hline Total & 60 & 100 & 60 & 100 \\
\hline
\end{tabular}


Taple 3. food habits

Girls

Boys

de

Girls Boys

Girls Boys

Variable

Frequency $\%$

Variable

Frequency $\% \quad$ Frequency $\%$

\begin{tabular}{|c|c|c|c|c|c|c|c|c|c|}
\hline \multicolumn{5}{|c|}{ 1. Meals number } & \multicolumn{5}{|c|}{ 5. Eating pickles } \\
\hline One & 1 & 1.67 & 3 & 5 & Yes & 29 & 48.33 & 19 & 31.67 \\
\hline Two & 21 & 35 & 16 & 26.67 & No & 15 & 25 & 24 & 40 \\
\hline Three & 36 & 60 & 35 & 58.33 & Sometimes & 16 & 26.67 & 17 & 28.33 \\
\hline More than 3 & 2 & 3.33 & 6 & 10 & \multicolumn{5}{|c|}{ 6. Quantity of salt in food } \\
\hline \multicolumn{5}{|c|}{ 2. Omitted meal } & Slight Slat & 8 & 13.33 & 3 & 5 \\
\hline None & 38 & 63.33 & 41 & 68.33 & Moderate salt & 49 & 81.67 & 45 & 75 \\
\hline Break fast & 10 & 16.67 & 16 & 26.67 & Heavy Salt & 3 & 5 & 12 & 20 \\
\hline Lunch & 11 & 18.33 & 0 & 0 & \multicolumn{5}{|c|}{ 7. Do you drink tea directly after meals? } \\
\hline Dinner & 1 & 1.67 & 3 & 5 & No & 14 & 23.33 & 16 & 26.67 \\
\hline \multicolumn{5}{|c|}{ 3. Cause of not eating breakfast } & Sometimes & 18 & 30 & 12 & 20 \\
\hline No time & 6 & 60 & 11 & 68.75 & Yes & 28 & 46.67 & 32 & 53.33 \\
\hline No Appetite & 2 & 20 & 0 & 0 & \multicolumn{5}{|c|}{ 8. number of Sugar spoon } \\
\hline $\begin{array}{c}\text { Non- } \\
\text { Habitual }\end{array}$ & 1 & 10 & 4 & 25.00 & One & 6 & 10 & 6 & 10 \\
\hline Don't His & 1 & 10 & 1 & 6.25 & Two & 15 & 25 & 16 & 26.67 \\
\hline \multicolumn{5}{|c|}{ 4. Kind of food snacking between meals } & Three & 27 & 45 & 30 & 50 \\
\hline No & 4 & 6.67 & 6 & 10 & More than 3 & 12 & 20 & 8 & 13.33 \\
\hline Sometimes & 3 & 5 & 7 & 11.67 & \multicolumn{5}{|c|}{ 9. Do you have soft drink? } \\
\hline Always & 53 & 88.33 & 47 & 78.33 & Yes & 22 & 36.67 & 14 & 23.33 \\
\hline Sweets & 8 & 1500 & 1 & 2.13 & No & 25 & 41.66 & 13 & 21.67 \\
\hline Juice & 11 & 18.33 & 9 & 15 & Sometimes & 13 & 21.67 & 33 & 55 \\
\hline Soft Drink & 5 & 8.33 & 4 & 6.67 & \multicolumn{5}{|c|}{ 10. Do you drink milk? } \\
\hline Sandwich & 2 & 3.33 & 4 & 6.67 & Yes & 19 & 31.67 & 10 & 16.67 \\
\hline \multirow[t]{2}{*}{ Fruit } & 22 & 36.67 & 8 & 13.33 & No & 11 & 18.33 & 26 & 43.33 \\
\hline & & & & & Sometimes & 30 & 50 & 24 & 40 \\
\hline
\end{tabular}

Table 4. Nutrition awareness

of

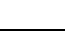


Table 4. Continue

\begin{tabular}{|c|c|c|c|c|c|c|c|c|}
\hline \multirow{3}{*}{ Statement } & \multicolumn{4}{|c|}{ Girls $(N=60)$} & \multicolumn{4}{|c|}{ Boys $(\mathrm{N}=60)$} \\
\hline & \multicolumn{2}{|c|}{ Yes } & \multicolumn{2}{|c|}{ No } & \multicolumn{2}{|c|}{ Yes } & \multicolumn{2}{|c|}{ No } \\
\hline & $\mathbf{N}$ & $\%$ & $\mathbf{N}$ & $\%$ & $\mathbf{N}$ & $\%$ & $\mathbf{N}$ & $\%$ \\
\hline Horse bean is a main source of protein in Egypt. & 52 & 86.67 & 8 & 13.33 & 55 & 91.67 & 5 & 8.33 \\
\hline The bread is a rich source of carbohydrates. & 49 & 81.67 & 11 & 18.33 & 47 & 78.33 & 13 & 21.67 \\
\hline \multicolumn{9}{|l|}{ Meat, fish and egg } \\
\hline $\begin{array}{l}\text { Meat protein is equivalent to fruits and vegetables } \\
\text { protein nutritional value. }\end{array}$ & 17 & 28.33 & 43 & 71.67 & 25 & 41.67 & 35 & 58.33 \\
\hline $\begin{array}{l}\text { Boiled meat has a higher nutritional value than } \\
\text { grilled or cooked meat by frying. }\end{array}$ & 33 & 55 & 27 & 45 & 27 & 45 & 33 & 55 \\
\hline $\begin{array}{l}\text { Fish is more useful than meat concerning the } \\
\text { nutritional value. }\end{array}$ & 44 & 73.33 & 16 & 26.67 & 51 & 85 & 9 & 15 \\
\hline $\begin{array}{l}\text { Eating fish and drinking milk causes mental } \\
\text { retardation }\end{array}$ & 23 & 38.33 & 37 & 61.67 & 26 & 43.33 & 34 & 56.67 \\
\hline Eggs substitute meat & 48 & 80 & 12 & 20 & 42 & 70 & 18 & 30 \\
\hline $\begin{array}{l}\text { Egg yolk has a higher nutritional value than egg } \\
\text { albumin }\end{array}$ & 43 & 71.67 & 17 & 28.33 & 37 & 61.67 & 23 & 38.33 \\
\hline White chicken meat is more healthy than red meat & 50 & 83.33 & 10 & 16.67 & 42 & 70 & 18 & 30 \\
\hline The liver is a rich source of iron & 45 & 75 & 15 & 25 & 40 & 66.67 & 20 & 33.33 \\
\hline Fish is rich of vitamins & 28 & 46.67 & 32 & 53.33 & 32 & 53.33 & 28 & 46.67 \\
\hline $\begin{array}{l}\text { Uncooked eggs are better than boiled and fried } \\
\text { ones }\end{array}$ & 38 & 63.33 & 22 & 36.67 & 30 & 50 & 30 & 50 \\
\hline \multicolumn{9}{|l|}{ Milk and dairy products group } \\
\hline $\begin{array}{l}\text { Pasteurized milk contains more vitamins than } \\
\text { boiled milk. }\end{array}$ & 41 & 68.33 & 19 & 31.67 & 47 & 78.33 & 13 & 21.67 \\
\hline Milk is rich of iron. & 11 & 18.33 & 49 & 81.67 & 25 & 41.67 & 35 & 58.33 \\
\hline $\begin{array}{l}\text { Cottage cheese has more nutritional value than } \\
\text { Roumi cheese. }\end{array}$ & 15 & 25 & 45 & 75 & 18 & 30 & 48 & 60 \\
\hline Milk is a rich source of calcium. & 59 & 98.33 & 1 & 1.67 & 47 & 78.33 & 13 & 21.67 \\
\hline Yoghurt is more digestible than fresh milk. & 25 & 41.67 & 35 & 58.33 & 40 & 66.67 & 20 & 33.33 \\
\hline $\begin{array}{l}\text { Drinking enough milk in the morning substitutes } \\
\text { breakfast. }\end{array}$ & 36 & 60 & 24 & 40 & 38 & 63.33 & 28 & 46.63 \\
\hline Margarine may lead to heart diseases & 42 & 70 & 18 & 30 & 46 & 76.67 & 14 & 23.33 \\
\hline Margarine is always healthy compared to oils. & 40 & 66.67 & 20 & 33.33 & 33 & 55 & 27 & 45 \\
\hline \multicolumn{9}{|l|}{ Fruits and vegetables groups and tea drinking } \\
\hline Peeled potatoes lose some of it's nutritional value & 26 & 43.33 & 34 & 56.67 & 28 & 46.67 & 32 & 53.33 \\
\hline $\begin{array}{l}\text { Boiled vegetables for salads is better than fresh } \\
\text { vegetables }\end{array}$ & 16 & 26.67 & 44 & 73.33 & 20 & 33.33 & 40 & 66.67 \\
\hline $\begin{array}{l}\text { Carrot contains nutrients nutritional which } \\
\text { strengthen eye-vision which strengthen eye-vision }\end{array}$ & 48 & 80 & 12 & 20 & 41 & 68.33 & 19 & 31.67 \\
\hline Pears are rich of iron & 41 & 68.33 & 19 & 31.67 & 33 & 55 & 27 & 45 \\
\hline Mango is rich of iron & 33 & 55 & 27 & 45 & 35 & 58.33 & 25 & 41.67 \\
\hline Spinach is rich of iron & 40 & 66.67 & 20 & 33.33 & 33 & 55 & 27 & 45 \\
\hline $\begin{array}{l}\text { Excess intakes of potatoes and sweet potatoes may } \\
\text { be a cause of a gaining weight. }\end{array}$ & 55 & 91.67 & 5 & 8.33 & 34 & 56.67 & 23 & 38 \\
\hline Vegetables and fruits are main source of vitamins & 35 & 58.33 & 25 & 41.67 & 37 & 61.67 & 23 & 38.33 \\
\hline Tomatoes are poor source of vitamins & 22 & 36.67 & 38 & 63.33 & 25 & 41.67 & 35 & 58.33 \\
\hline Drinking tea after meals may lead to anemia & 51 & 85 & 9 & 15 & 49 & 81.67 & 11 & 18.33 \\
\hline \multicolumn{9}{|l|}{ Fats and sugar group } \\
\hline $\begin{array}{l}\text { Simple sugar is better than complex sugar (starch } \\
\text { sources) }\end{array}$ & 10 & 16.67 & 50 & 83.33 & 25 & 41.67 & 35 & 58.33 \\
\hline
\end{tabular}


Table 4. Continue

\begin{tabular}{|c|c|c|c|c|c|c|c|c|}
\hline \multirow{3}{*}{ Statement } & \multicolumn{4}{|c|}{ Girls ( $N=60$ ) } & \multicolumn{4}{|c|}{ Boys $(\mathrm{N}=60)$} \\
\hline & \multicolumn{2}{|c|}{ Yes } & \multicolumn{2}{|c|}{ No } & \multicolumn{2}{|c|}{ Yes } & \multicolumn{2}{|c|}{ No } \\
\hline & $\mathbf{N}$ & $\%$ & $\mathbf{N}$ & $\%$ & $\mathbf{N}$ & $\%$ & $\mathbf{N}$ & $\%$ \\
\hline $\begin{array}{l}\text { The nutritional value for sweets comes mostly from } \\
\text { sugar }\end{array}$ & 33 & 55 & 27 & 45 & 30 & 50 & 30 & 50 \\
\hline Fats provide bodies with the required energy & 40 & 66.67 & 20 & 33.33 & 32 & 53.33 & 28 & 46.67 \\
\hline $\begin{array}{l}\text { The more the muscle exercises (effort) the more } \\
\text { sugar and fats are needed }\end{array}$ & 52 & 86.67 & 8 & 33.33 & 45 & 57 & 15 & 25 \\
\hline $\begin{array}{l}\text { The more weight gain for individual required for } \\
\text { more sugar and fats intakes with less movement }\end{array}$ & 37 & 61.67 & 23 & 38.33 & 27 & 45 & 33 & 55 \\
\hline $\begin{array}{l}\text { High fat intake may cause heart diseases and } \\
\text { hypertension }\end{array}$ & 4.9 & 81.67 & 11 & 18.33 & 39 & 65 & 21 & 35 \\
\hline Vegetable oil is better for health than animal fat . & 14 & 23.33 & 46 & 76.67 & 22 & 36.67 & 38 & 63.33 \\
\hline \multicolumn{9}{|l|}{ Vitamins and minerals group: } \\
\hline $\begin{array}{l}\text { Cutting then washing fresh vegetables several times } \\
\text { cause a great loss in vitamins }\end{array}$ & 10 & 16.67 & 50 & 83.33 & 9 & 15 & 51 & 85 \\
\hline $\begin{array}{l}\text { Vitamins are essential to protect the body against } \\
\text { disease }\end{array}$ & 44 & 73.33 & 16 & 26.67 & 41 & 68.33 & 19 & 31.67 \\
\hline $\begin{array}{l}\text { The vitamins are essential to protect the } \\
\text { adolescents from catching cold. }\end{array}$ & 47 & 78.33 & 13 & $21 . .67$ & 43 & 71.63 & 17 & 28.33 \\
\hline Salts are important for building body & 43 & 71.67 & 17 & 28.33 & 39 & 65 & 21 & 35 \\
\hline $\begin{array}{l}\text { Honey is essential to protect the body against } \\
\text { disease. }\end{array}$ & 52 & 86.67 & 8 & 13.33 & 48 & 80 & 12 & 20 \\
\hline Cane syrup (black honey) is rich in iron & 53 & 88.33 & 7 & 11.67 & 50 & 83.33 & 10 & 16.67 \\
\hline $\begin{array}{l}\text { Iron mineral intake from food protects the body } \\
\text { against anemia }\end{array}$ & 41 & 68.33 & 19 & 31.67 & 50 & 83.33 & 10 & 16.67 \\
\hline
\end{tabular}

Both groups however lack for more nutritional awareness. More boys (76.67\%) than girls (70\%) reported right that margarine may lead to heart attack, which is possibly due to much free radical.(Robert,E et al., 2006).

Results presented in table (4) show the frequency distribution of adolescents concerning to their opinion about the fruits and vegetables group. It is obvious that both boys $(53.33 \%)$ and girls (56.67\%) reported wrongly that peeled potatoes do not lose some of its nutritional value. Unfortunately, more than half the answers were wrong regardless of gender. Boys $(61.67 \%)$ and girls $(58.33 \%)$ believed right that vegetables and fruits are main sources of vitamins (Lytle, L 2002)

Results presented in table (4) show more girls $(83.33 \%)$ than boys $(58 \%)$ were right when they said that simple sugar is not better than the complex sugar sources. But unfortunately, tangible proportions of girls (16.67\%) and boys $41.67 \%$ were wrong. About half the total sample (55\% of girls, $50 \%$ of boys) was wrong. Showing that nutritional value of sweets comes from sugar, neglecting, for instance, milk and nuts. The results however, were in behalf of girls.

From the results in table (4), it is evident that both girls $(83.33 \%)$ and boys $(85 \%)$ were mistaken when saying that cutting then washing cut fresh vegetables several times do not cause a great loss in vitamins. Most of girls $(78.33 \%)$ and boys $(71.67 \%)$ knew that vitamins are essential to protect adolescents from catching cold.

\section{E- Daily intake of nutrients:}

The results of table (5) show the macronutrients intake by adolescents of both genders. It is obvious that both girls $(88.53 \%)$ of DRI and boys (74.09\%) were low in total calories intake, provided that total, however calories intake by girls was higher than for the boys. Total fat intake for girls (90.12\% of DRI) and boys (75.20\% of DRI) was less than DRI in particular for boys. The low fat than DRI mean possibly less intakes of vitamins such as Vits. A and D.

From results of table (5), it could be noticed that the intakes of vitamins A, D and B1 were higher for boys than girls, while the intakes of vitamins E, B2 and B12 were higher for girls than boys. The intakes of vitamins $\mathrm{C}$, niacin and folate were similar for both genders. Nevertheless, a high significant difference was recorded for vitamins D, B1 and B2 and very high significant difference recorded Vits. B12.

The results of table (5) show the daily intake of adolescents from diet minerals. It was found that sodium intake was evidently higher than the DRI, being $175.57 \%$ of DRI in girls and $179.10 \%$ of DRI for boys. 
Table 5. Daily Intake of macronutrition, vitamin and miner

\begin{tabular}{|c|c|c|c|c|c|c|c|}
\hline \multirow[b]{2}{*}{ Nutrient } & \multicolumn{3}{|c|}{ Girls } & \multicolumn{3}{|c|}{ Boys } & \multirow[b]{2}{*}{ sig } \\
\hline & Mean \pm SD & DRI & $\begin{array}{l}\text { \% of } \\
\text { DRI }\end{array}$ & Mean \pm SD & DRI & $\begin{array}{l}\text { \% of } \\
\text { DRI }\end{array}$ & \\
\hline \multicolumn{8}{|c|}{ Macronutrients } \\
\hline Energy(kcal) & $2077.87 \pm 53$ & $\begin{array}{c}2347.0 \\
8\end{array}$ & 88.53 & $2020.49 \pm 41$ & 2727.02 & 74.09 & $* *$ \\
\hline Animal protein $(\mathrm{g})$ & $27.02 \pm 1.3$ & \multirow{3}{*}{34} & \multirow{3}{*}{198.97} & $30.49 \pm 1.74$ & \multirow{3}{*}{34} & \multirow{3}{*}{213.97} & \\
\hline Plant protein $(\mathrm{g})$ & $40.63 \pm 2.9$ & & & $42.26 \pm 2.76$ & & & \\
\hline Total protein $(\mathrm{g})$ & $67.65 \pm 0.3$ & & & $72.75 \pm 1.99$ & & & \\
\hline Animal fat $(\mathrm{g})$ & $30.71 \pm 14.59$ & \multirow{3}{*}{78.24} & \multirow{3}{*}{90.12} & $23.44 \pm 2.06$ & \multirow{3}{*}{90.90} & \multirow{3}{*}{75.20} & \\
\hline Plant fat $(\mathrm{g})$ & $39.8 \pm 2.3$ & & & $44.92 \pm 14.67$ & & & \\
\hline Total fat $(\mathrm{g})$ & $70.51 \pm 3.5$ & & & 68.36 & & & \\
\hline Carbohydrate(g) & $293.17 \pm 7.9$ & 376.73 & 77.82 & $280.81 \pm 40.63$ & 25 & 443.23 & $*$ \\
\hline Fiber $(\mathrm{g})$ & $7.9 \pm 2.0$ & 31 & 25.48 & $6.5 \pm 1.99$ & 25 & 26 & \\
\hline Cholesterol(g) & $12.79 \pm 3.4$ & 200 & 63.95 & $11.71 \pm 2.96$ & 25 & 200 & \\
\hline \multicolumn{8}{|c|}{ Vitamins } \\
\hline Vitamin $\mathrm{A}(\mu \mathrm{g})$ & $1360 \pm 1.86$ & 600 & 80 & $1420 \pm 1.78$ & 600 & 83.53 & \\
\hline Vitamin $\mathrm{D}(\mu \mathrm{g})$ & $1.97 \pm 0.80$ & 5 & 39.4 & $2.43 \pm 0.84$ & 5 & 48.6 & $*$ \\
\hline Vitamin $E(\mu \mathrm{g})$ & $11.9 \pm 0.29$ & 11 & 108.18 & $11.2 \pm 0.31$ & 11 & 101.82 & \\
\hline Vitamin $\mathrm{C}(\mathrm{mg})$ & $12.3 \pm 0.26$ & 45 & 27.33 & $12.3 \pm 0.28$ & 45 & 27.33 & \\
\hline Vitamin $\mathrm{B} \square(\mathrm{mg})$ & $2.40 \pm 1.2$ & 0.9 & 266.67 & $2.49 \pm 1.32$ & 0.9 & 276.67 & $*$ \\
\hline Vitamin B2 (mg) & $1.51 \pm 0.4$ & 0.9 & 167.78 & $1.37 \pm 0.55$ & 0.9 & 152.22 & $*$ \\
\hline Vitamin B12 (mg) & $2.69 \pm 0.62$ & 1.8 & 149.44 & $2.27 \pm 0.11$ & 1.8 & 126.11 & $* *$ \\
\hline Niacin (mg) & $8.9 \pm 0.72$ & 12 & 74.75 & $8.6 \pm 0.08$ & 12 & 72.17 & \\
\hline Folate (mg) & $269.42 \pm 89.42$ & 300 & 89.81 & $268.43 \pm 88.16$ & 300 & 89.48 & \\
\hline \multicolumn{8}{|c|}{ Mineral } \\
\hline Sodium (mg) & $2633.60 \pm 413.0$ & 1500 & 175.57 & $2686.48 \pm 361.11$ & 1500 & 179.1 & $*$ \\
\hline Potassium(mg) & $1141 \pm 11.09$ & 4500 & 25.33 & $1109 \pm 3.55$ & 4500 & 42.64 & \\
\hline Calcium (mg) & $506.26 \pm 76.34$ & 130 & 38.94 & $477.05 \pm 93.09$ & 1300 & 36.69 & $* *$ \\
\hline Magnesium (mg) & $115.58 \pm 23.60$ & 240 & 481.16 & $68.31 \pm 8.26$ & 240 & 28.39 & $*$ \\
\hline Phosphorus (mg) & $1165.68 \pm 56.86$ & 1250 & 93.35 & $1122.61 \pm 17.92$ & 1250 & 89.81 & $* *$ \\
\hline Animal Iron (mg) & $3.16 \pm 0.82$ & \multirow{3}{*}{8} & \multirow{3}{*}{76.63} & $2.5 \pm 0.32$ & \multirow{3}{*}{8} & \multirow{3}{*}{69.5} & \multirow{3}{*}{$*$} \\
\hline Plant Iron (mg) & $2.97 \pm 0.29$ & & & $3.06 \pm 0.21$ & & & \\
\hline Total Iron (mg) & $6.13 \pm 0.5$ & & & $5.56 \pm 0.3$ & & & \\
\hline Zinc (mg) & $2.4 \pm 0.17$ & 8 & 30.13 & $2.22 \pm 0.53$ & 8 & 27.75 & $*$ \\
\hline
\end{tabular}

Differences between girls and boys were significant; high intakes of sodium lead to hypertension. The low intakes of total iron (76.63 and $69.50 \%$ of DRI in girls and boys respectively) is a threaten of anemia, which is a dangerous disease for adolescents.

Data of table (6) show the number of girls and boys inflicted with some diseases or not. It is clear that 8.33 $\%$ of girls and $13.33 \%$ of boys were suffering of anemia. This went parallel with the results of table (5-c) here the daily intake of adolescents were less than DRI, in particular the boys. Boys and girls reported that they suffer of hair fall (15 and 38.33\%) of total sample). This coincided with the results of Tables (5-b and 5-c) where both groups showed low intakes of $\mathrm{Fe}$ and some $\mathrm{B}$ vitamins. (Michael, J. G. et al., 2004).

Finally, it could be concluded that the knowledge of students regardless on their gender showed in complete awareness considering their health and nutritional status.

It may be recommended that nutritional educational programs should be directed both adolescent girls and boys.

Evaluation of nutritional and health status of adolescents in preparatory schools should carried out periodically because the prices of foods are changed rapidly. 
Table 6. Healths status

\begin{tabular}{|c|c|c|c|c|}
\hline \multirow[b]{2}{*}{ Variable } & \multicolumn{2}{|c|}{ Girls } & \multicolumn{2}{|c|}{ Boys } \\
\hline & Frequency & $\%$ of total & Frequency & $\%$ of total \\
\hline \multicolumn{5}{|c|}{ 1. Suffer of hypertension: } \\
\hline Yes & 9 & 15 & 16 & 26.67 \\
\hline No & 34 & 56.67 & 25 & 41.66 \\
\hline Sometimes & 17 & 28.33 & 19 & 31.67 \\
\hline \multicolumn{5}{|c|}{ 2. Suffer from troubles and digestion: } \\
\hline Yes & 8 & 13.33 & 10 & 16.67 \\
\hline No & 37 & 61.67 & 34 & 56.66 \\
\hline Sometimes & 15 & 25 & 16 & 26.67 \\
\hline \multicolumn{5}{|c|}{ 3. Suffer from hair loss: } \\
\hline Yes & 23 & 38.33 & 9 & 15 \\
\hline No & 28 & 46.67 & 34 & 56.67 \\
\hline Sometimes & 9 & 15 & 17 & 28.33 \\
\hline \multicolumn{5}{|l|}{ 4. Suffer from anemia: } \\
\hline Yes & 5 & 8.33 & 8 & 13.33 \\
\hline No & 48 & 80 & 36 & 60 \\
\hline Sometimes & 7 & 11.67 & 16 & 26.67 \\
\hline \multicolumn{5}{|c|}{ 5. Suffer from teeth decay: } \\
\hline Yes & 22 & 36.67 & 11 & 18.33 \\
\hline No & 30 & 50 & 40 & 66.67 \\
\hline Sometimes & 8 & 13.33 & 9 & 15 \\
\hline \multicolumn{5}{|c|}{ 6. Suffer from canker of teeth gum: } \\
\hline Yes & 19 & 31.67 & 15 & 25 \\
\hline No & 26 & 43.33 & 34 & 56.67 \\
\hline Sometimes & 15 & 25 & 11 & 18.33 \\
\hline \multicolumn{5}{|c|}{ 7. Feel with tiredness and lazyness: } \\
\hline Yes & 15 & 25 & 15 & 25 \\
\hline No & 17 & 28.33 & 15 & 25 \\
\hline Sometimes & 28 & 46.67 & 30 & 50 \\
\hline \multicolumn{5}{|c|}{ 8.Suffer from angular stomatits: } \\
\hline Yes & 11 & 18.33 & 16 & 26.67 \\
\hline No & 33 & 55 & 27 & 45 \\
\hline Sometimes & 16 & 26.67 & 17 & 28.33 \\
\hline \multicolumn{5}{|l|}{ 9. Take any medicine : } \\
\hline Yes & 11 & 18.33 & 8 & 13.33 \\
\hline No & 30 & 50 & 37 & 61.67 \\
\hline Sometimes & 19 & 31.67 & 15 & 25 \\
\hline 10.Knd of medicine & & $=23$ & & \\
\hline Vitamins & 5 & 16.67 & 6 & 26.08 \\
\hline Obtundent & 9 & 30 & 6 & 26.08 \\
\hline sedatives & 8 & 26.66 & 5 & 21.74 \\
\hline Antibiotic & 5 & 16.67 & 4 & 17.4 \\
\hline Other & 3 & 10 & 2 & 8.4 \\
\hline \multicolumn{5}{|c|}{ 11.Do you wash your teeth with toothbrush: } \\
\hline Yes & 22 & 36.67 & 30 & 50 \\
\hline No & 18 & 30 & 10 & 16.67 \\
\hline Sometimes & 20 & 33.33 & 20 & 33.33 \\
\hline \multicolumn{5}{|l|}{ 12.Do you play sport : } \\
\hline Yes & 20 & 33.33 & 28 & 46.67 \\
\hline No & 25 & 41.67 & 14 & 23.33 \\
\hline Some times & 15 & 25 & 18 & 30 \\
\hline
\end{tabular}




\section{REFERENCES}

Al Sabbah, H. ; Vereecken, C.; Kolsteren, P; Abdeen, Z. and Maes, L.(2004): Food habits and physical activity patterns among Palestinian adolescents: Findings from the national study of Palestinian schoolchildren (HBSC-WBG2004). Public Health Nutr. 10(7):739-46.

Bendary, S. A. (1997): Food consumption Pattern and Food Preference among Preparatory School Public in AlSharkia Governorate and their Correlation with their Families Social Variables. M.Sc. Thesis, Faculty of Home Economics, Menoufia University.

Croll, J.; Newmark-sztainer, D. and Story,M. (2001):Health eating. What does it mean to adolescent? Journal of Nutrition Esucation, 33(4); 193-198.

Diet Analysis Program (1995): Computer Program Ready to Eat Egyptian Foods, Version 1. Food Analysis and Statistical analysis Unit Faculty of Home Economics, Menoufia University

DRI (2002): Dietary Reference intake for Energy, Carbohydrate, Fiber, Fatty acids, Cholesterol. Institute Medicine, I. O. .N.

Filer, L. J. (1993): A summary of the workshop on child adolescent obesity: What, How and Who? Critical Reviews of Food Science and Nutrition ,33 (4/5): 287305 .
Kirby, M. and Danner, E.(2009): Nutritional deficiencies in children on restricted diets., Pediatr Clin North Am; 56(5):1085-103.

Lytle, L. A. (2002): Nutritional issues for adolescents. J. Am. Diet Assoc; 102 (3):S8-12.

Michael, J.; Barrie, M.; John, M. and Lenore, A.(2004): Public Health Nutrition.ISBN 0-632-05627-4.

Peykari, N.; Tehrani, F.R.; Eftekhari, M. B.; Malekafzali, H. Dejman, M. Neot, R. and Djalalinia, S .(2011): A peerbased study on adolescence nutritional health: Alesson learned from Iran. J Pak Med Assoc.; 61(6):549-54.

RDA(1989): Recommended Dietary Allowance .10 ${ }^{\text {th }}$ Edition The national academy of Science, National Academy Press, Washington ,D.c.

Robert, E. ; Wildman, D. and Medeiros, (2006): Advanced Human Nutrition. Crc press, Bocca Roton London New York Washington, D.C.

Spss(1998): Statistical Package for Social Science .Computer Software, Ver.10.spss Company, Lodon .

Unicef, (2010): Child Poverty and Disparities in Egypt. www.unicef.org/Egypt.

Usfar, A. A. and Fahmida, U. (2011): Evidence related to food consumption, healthy lifestyle, and nutritional status within the period 2000-2010, Asia Pac J Clin Nutr.; 20(3):484-94.

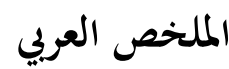

\section{تقييم الحالة الغذائية والصحية لطلبة المدارس الاعدادية قويسنا- المنوفية}

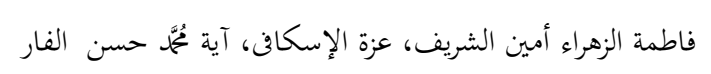

ولقد وجد ان الوعى الغذائى كان منخفضا لكال الجنسين بالنسبة

لكثير من نقـاط البحث خاصة للأولاد مما يستدعى إلى استهدافهم

ببرامج توعية غذائية كما إتضح أن المأخوذ اليومى كان منخفضا فيما

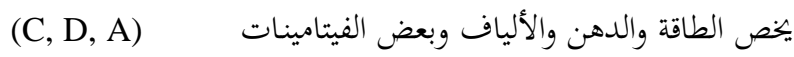

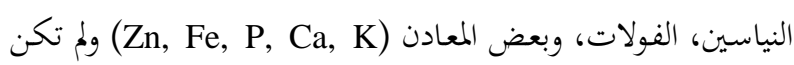

$$
\text { الحالة الصحية مرضية بالنسبة للأولاد والبنات على السواء. }
$$

(الحالة التغذوية، الحالة الصحية، العادات الغذائية، المقاييس الجسمية،

$$
\text { المأخوذ اليومى للعناصر الغذائية). }
$$

$$
\begin{aligned}
& \text { يعتبر في الحد الأقصى من الأهمية أن نتعرف على الحالة التغذوية } \\
& \text { والصحية للمراهقين، حيث أفهم سيكونون هم العمالة في هذه المنطقة } \\
& \text { المستقبلية. وعلى الأخـص فـإن المـراهقين الريفيـون مثلمـا في محافظة }
\end{aligned}
$$

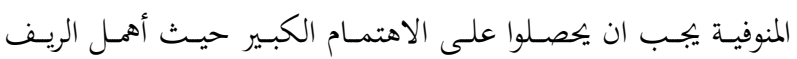

$$
\begin{aligned}
& \text { لسنوات طويلة. } \\
& \text { ولقـد تم الاختيـار عشـوائيا لـ } 60 \text { مسن الأناث و60 مسن الـذكور } \\
& \text { بعمـر 11- } 14 \text { سـنة مسن المـدارس الاعداديـة لشببين الكـوم- محافظة } \\
& \text { المنوفية وتم الحصول على مقاييسهم الجسمية. كما استخدم استبيان } \\
& \text { يتضـمن العوامـل الاقتصـادية والاجتماعيـة، العـادات الغذائيـة، المأخوذ } \\
& \text { اليومى من العناصر الغذائية وجعت المعلومات من خلال مقابلات مع } \\
& \text { البـاحثين كمـا أجـرى التحليـل الاحصـائى باستخدام بـرنامج SPSS }
\end{aligned}
$$$$
\text { . لl }
$$ 
